\title{
Potential of Underutilized Marine Organisms for Aquaculture Feeds
}

\author{
Dedi Jusadi ${ }^{\dagger}$, Julie Ekasari ${ }^{*+}$, Muhammad Agus Suprayudi, Mia Setiawati and \\ Ichsan Achmad Fauzi
}

Department of Aquaculture, Faculty of Fisheries and Marine Sciences, Bogor Agricultural University, Bogor, Indonesia

\section{OPEN ACCESS}

Edited by:

Alan T. Critchley,

Cape Breton University, Canada

Reviewed by:

Najiah Musa,

University of Malaysia

Terengganu, Malaysia

Nor Azman Kasan

University of Malaysia

Terengganu, Malaysia

Richard Cottrell,

University of California, Santa Barbara,

United States

*Correspondence:

Julie Ekasar

j_ekasari@apps.ipb.ac.id

tThese authors have contributed equally to this work and share first authorship

Specialty section:

This article was submitted to Marine Fisheries, Aquaculture and

Living Resources,

a section of the journal

Frontiers in Marine Science

Received: 23 September 2020 Accepted: 28 December 2020

Published: 11 February 2021

Citation:

Jusadi D, Ekasari J, Suprayudi MA,

Setiawati M and Fauzi IA (2021)

Potential of Underutilized Marine

Organisms for Aquaculture Feeds.

Front. Mar. Sci. 7:609471.

doi: 10.3389/fmars.2020.609471
The supply of land-based agricultural products as aquafeed raw materials is challenged by limitations on space and water, and by environmental damage. Marine environments offer a vast opportunity for the expansion of aquaculture, including the production of feed raw materials. Besides fishmeal and fish oil, which are generated from capture fisheries, the use of marine-based feed raw materials from aquaculture production is not yet in common practice. Here, we discuss the potential of underutilized marine organisms that can be cultured by extracting nutrients from their environment and are nutritionally compatible for use as alternative feed materials in aquaculture. We identify marine organisms such as blue and green mussels, Ulva spp., and microbial floc that are nutritionally suitable as aquafeed raw material and may further act as bioremediators. However, environmental factors that affect productivity and the risk of pollutant accumulations, which would potentially reduce the safety of aquaculture products for human consumption, may pose challenges to such applications of extractive organisms. Therefore, the development of pretreatment and processing technologies will be critical for improving the nutritional quality and safety of these raw materials for aquafeed production.

Keywords: aquafeed, bioremediation, extractive organisms, macroalgae, shellfish, microalgae

\section{INTRODUCTION}

Aquaculture is expected to meet the majority of the demand for seafood, given that capture fisheries have been in stagnation for the last few decades (FAO, 2020). However, the development of aquaculture production is challenged by limitations on pivotal resources such as space, water, and feed raw materials. Aquaculture products can be classified into two groups, i.e., fed organisms, which are cultured with the addition of external feed, and unfed organisms, which are cultured without the addition of external feed (Hua et al., 2019; FAO, 2020). At present, most aquaculture activities produce fed organisms that rely heavily on formulated feed. Thus, the increase in aquaculture production has a generally linear relationship with the increase in feed production (FAO, 2020). The inclusion of fishmeal and fish oil, a common source of protein and lipids in aquafeeds in decades, has substantially declined due to rising prices of these products and the sustainability concerns over the harvesting of small pelagic fish used to produce them (Hua et al., 2019). As a result, most raw materials in aquafeed are now agricultural products produced in terrestrial systems where water, space, and other environmental resources have become scarce. The marine ecosystem, on the other hand, offers vast opportunities for the production of produce seafood products and aquafeed raw materials (Gentry et al., 2017). 
The intense competition for raw materials due to other human uses, which affects aquafeed supply, is a major motivation for the aquaculture sector to generate its own feed raw materials from marine sources. The demand for high-quality materials for various human-related applications has been increasing, creating more opportunities for the aquaculture sector to produce marine-based high-quality raw materials for various human needs, including other food-producing sectors such as livestock production. Aquafeed raw material exploration should focus on unfed marine organisms, which can act as bioremediators that extract waste nutrients from the environment and convert them into beneficial biomass that may be used as feed raw materials (Agarwal et al., 2020). Here, we discuss the potential use of some underutilized marine organisms as candidates for raw materials in aquafeed, with specific emphasis given to unfed low-trophiclevel organisms such as shellfish, seaweed, and microorganisms.

\section{SELECTION CRITERIA FOR AQUAFEED RAW MATERIALS}

The following criteria should be considered when selecting appropriate aquafeed raw material: (1) nutritional value relative to the requirement of the cultured animal and its digestibility by the target animal; (2) the presence of antinutritional factors (ANFs) and contaminants; (3) supply reliability; and (4) price volatility (Glencross et al., 2020). The nutritional composition and digestibility of feed materials have synergistic effects on growth outcomes of fed aquaculture species. In addition, the physical and nutritional qualities of raw materials should also include their characteristics during manufacturing processes and how they affect the pellet quality (Turchini et al., 2019). High digestibility ensures high nutrient bioavailability and utilization by the animal. The presence of antinutritional factors, i.e., substances that could interfere with food utilization and negatively affect the health and production of animals, is an important factor determining the nutritional feasibility of a raw material for aquafeed (Francis et al., 2001). In addition, marine-origin raw material may carry the risk of contamination by heavy metals and toxins, with potential direct or indirect adverse effects on the fed organisms and final consumers. In the aquafeed industry, the use of materials with routine and consistent supply is critical to reduce the risks of fluctuations in product quality and specification, cross-contamination, and shortfalls in supply during manufacturing (Glencross et al., 2020). Thus, continuous supply of a particular raw material in bulk quantities should be one of the major considerations when selecting potential raw material for aquafeed. The price volatility of a raw material, which is strongly influenced by its supply and demand, is the main economic factor affecting profitability in aquafeed manufacturing. In the context of raw material production, the supply of a raw material in bulk at an affordable price implies that the culture productivity, i.e., production per unit of area or per unit of water, and the processing cost of the marine-origin raw material should be comparable to that for the production of existing terrestrial-based raw materials. How new raw materials influence the environmental and social sustainability of aquafeeds are also critical considerations in the development of new feed products (Valenti et al., 2018). However, here, we focus on the technical potential of new ingredients as a first step for scoping novel raw materials of interest for the aquafeed industry.

\section{POTENTIAL MARINE UNFED ORGANISMS AS FEED RAW MATERIALS}

In this minireview, our focus is mainly given to macro- and microscopic organisms that are high in productivity and can be cultured by using nutrient waste or by-products, either in open marine environments or in enclosures in coastal areas. Based on these criteria, we identify some marine organisms that are potentially useful for aquafeed; these are classified into three groups: of animal, macroalgae, and microscopic origins (Table 1).

\section{Animal-Origin Materials}

Marine-animal-origin feed raw materials are mostly used as sources of essential amino acids and essential fatty acids for most aquaculture animals. There are at least three animal-origin materials that have the potential to be used as a protein source in aquafeed: mussels, artemia, and amphipods. These animals are low-trophic-level organisms that extract nutrients from primary producers such as microalgae and/or particulate organic matters in the aquatic environment. Mussels such as green (Perna viridis) and blue (Mytilus edulis) are extractive organisms that grow rapidly in nutrient-rich environments and act as bioremediator agents converting waste nutrients into the protein. Mussels contain considerably high protein [50-70\% dry weight (DW)] and lipid (5-16\% DW) levels, with comparable essential amino and fatty acids contents to those of fishmeal (Jusadi et al., 2020). A number of studies demonstrated that mussels are a promising protein source in aquafeed, with a reported maximum inclusion level of up to 25\% (Weiß and Buck, 2017; Jusadi et al., 2020). From an ecological perspective, mussels have been considered to play some important roles in carbon fixation and mitigation of ocean eutrophication (for a detailed review, see Suplicy, 2020). Artemia nauplii have been used as an important live food in almost all aquaculture hatchery productions. However, the supply of Artemia nauplii has been heavily reliant on cysts collected from the wild. Thus, many efforts have been undertaken to culture Artemia to produce cysts. Moreover, the use of adult Artemia as feed has started to gain attention. Artemia can be cultured at a relatively high productivity (ca. 2 tons/ha/crop) in shallow ponds by using by-products or waste as their feed (Anh et al., 2009b). The protein content of Artemia biomass is relatively high, e.g., a range of 51-61\% DW, with a lipid content ranging from 5 to 10\% DW (Anh et al., 2009a). Amphipods are another small crustacean that can grow rapidly in nutrient-rich areas. A recent study by Herawati et al. (2020) showed that Phronima sp. cultured using microalgae and cow manure could be used as the sole food for Pacific white shrimp postlarvae. 
TABLE 1 | Nutritional compositions of some underutilized marine organisms and its utilization as feed raw materials in aquaculture.

\begin{tabular}{|c|c|c|c|c|c|c|c|c|c|}
\hline Material & Species & $\begin{array}{l}\text { Protein } \\
\text { (\% DW) }\end{array}$ & $\begin{array}{l}\text { Lipid } \\
\text { (\% DW) }\end{array}$ & $\begin{array}{l}\text { Carbohydrate } \\
\text { (\% DW) }\end{array}$ & $\begin{array}{c}\text { Fiber } \\
(\% \text { DW })\end{array}$ & $\begin{array}{c}\text { Ash } \\
(\% \text { DW) }\end{array}$ & Target species & $\begin{array}{l}\text { Dietary } \\
\text { inclusion } \\
(\%)\end{array}$ & References \\
\hline \multicolumn{10}{|l|}{ Animal origin } \\
\hline \multirow[t]{2}{*}{ Mussels } & Mytillus edulis & $52-70$ & $7-16$ & 13 & 1.4 & $9-11$ & $\begin{array}{l}\text { Scophthalmus maximus, Solea solea, } \\
\text { Salvelinus alpinus, Perca fluviatilis }\end{array}$ & 25 & $\begin{array}{l}\text { Mongile et al., 2015; Langeland } \\
\text { et al., 2016; Weiß and Buck, } \\
\text { 2017; Wagner et al., } 2019\end{array}$ \\
\hline & Perna viridis & 53.9 & 11.2 & & 0.1 & 8.9 & Oreochromis niloticus & 10 & Jusadi et al., 2020 \\
\hline Artemia & Artemia biomass & $50.7-61.4$ & $4.9-9.9$ & & $2.5-16.6$ & 25.0 & Macrobrachium rosenbergii & $57.5-100$ & Anh et al., 2009a \\
\hline Amphipods & Phronima sp. & 40.3 & 15.1 & 10.0 & 8.9 & 17.2 & Litopenaeus vannamei & 100 & Herawati et al., 2020 \\
\hline \multicolumn{10}{|c|}{ Macroalgal origin } \\
\hline \multirow[t]{5}{*}{ Chlorophyta } & Ulva lactuca & $11.5-32.2$ & $0.5-6.1$ & 43.5 & $9.1-15.0$ & $24.4-33.2$ & $\begin{array}{l}\text { Clarias gariepinus, Sparus aurata, Oreochromis } \\
\text { niloticus, Litopenaeus vannamei }\end{array}$ & $5-25$ & $\begin{array}{l}\text { Abdel-Warith et al., 2016; } \\
\text { Shpigel et al., 2017; } \\
\text { Suryaningrum et al., 2017; } \\
\text { Laramore et al., 2018; Guerreiro } \\
\text { et al., } 2019\end{array}$ \\
\hline & Ulva rigida & $8.0-29.5$ & $0.2-2.0$ & $46.8-50.4$ & 12.3 & $4.5-26.7$ & $\begin{array}{l}\text { Sparus aurata, Oreochromis niloticus, Cyprinus } \\
\text { carpio, Onchorhyncus mykiss }\end{array}$ & $5-25$ & $\begin{array}{l}\text { Diler et al., 2007; Ergün et al., } \\
\text { 2009; Güroy et al., 2013; } \\
\text { Vizcaíno et al., } 2016\end{array}$ \\
\hline & Ulva sp. & 5.3 & $0.3-2.7$ & & $5.2-5.3$ & $24.7-46.0$ & $\begin{array}{l}\text { Oreochromis niloticus, Litopenaeus vannamei, } \\
\text { Scatophagus argus, Argyrosomus japonicus }\end{array}$ & $6-25$ & $\begin{array}{l}\text { Silva et al., 2015; Madibana } \\
\text { et al., 2017; Qiu et al., 2018; } \\
\text { Yangthong and Ruensirikul, } 2020\end{array}$ \\
\hline & Caulerpa lentilifera & $19.4-29.2$ & $0.8-2.9$ & $44.0-53.5$ & 4.1 & $16.6-29.6$ & Oreochromis niloticus, Penaeus monodon & $5-20$ & $\begin{array}{l}\text { Nagappan and Vairappan, 2014; } \\
\text { Putri et al., 2017; Putra et al., } \\
2019\end{array}$ \\
\hline & Caulerpa racemosa & $17.3-30.0$ & $1.8-2.1$ & $42.7-52.8$ & $3.1-3.3$ & $22.2-26.7$ & Penaeus monodon & & $\begin{array}{l}\text { Nagappan and Vairappan, 2014; } \\
\text { Puspitasari et al., } 2019\end{array}$ \\
\hline \multirow[t]{4}{*}{ Rhodophyta } & Gracilaria arcuata & 13.5 & 7.0 & & & 31.9 & Clarias gariepinus, Oreochromis niloticus, & 10 & $\begin{array}{l}\text { Al-Asgah et al., 2016; Younis } \\
\text { et al., } 2018\end{array}$ \\
\hline & Gracilaria lemaneiformis & 18.9 & 0.5 & & & & Acanthopagrus Schlegelii, Pagromus major & $3-15$ & Xuan et al., 2013, 2019 \\
\hline & Gracilaria pygmaea & 16.7 & 1.0 & & 1.2 & 29.5 & Onchorhyncus mykiss & 6 & Sotoudeh and Jafari, 2017 \\
\hline & Gracilaria cornea & 13.5 & 0.8 & 39.8 & & 35.6 & Sparus aurata & 25 & Vizcaíno et al., 2016 \\
\hline \multirow[t]{3}{*}{ Phaeophyta } & Macrocystis pyrifera & 6.1 & 0.7 & 44.2 & 10.5 & 31.1 & Litopenaeus vannamei, Onchorhyncus mykiss & $1.5-3.3$ & $\begin{array}{l}\text { Cruz-SuÁrez et al., 2009; } \\
\text { Dantagnan et al., } 2009\end{array}$ \\
\hline & Sargassum horneri & $13.2-17.2$ & $0.5-1.3$ & 63.0 & & $11.7-19.4$ & $\begin{array}{l}\text { Acanthopagrus schlegelii, Scophthalmus } \\
\text { maximus }\end{array}$ & $6-10$ & $\begin{array}{l}\text { Shi et al., 2019; Wang et al., } \\
2019\end{array}$ \\
\hline & Sargassum illicifolium & 9.2 & 2.1 & 33.1 & 10.3 & 29.2 & Litopenaeus vannamei, Huso huso & $7.5-15$ & $\begin{array}{l}\text { Hafezieh et al., 2014; Yeganeh } \\
\text { and Adel, } 2019\end{array}$ \\
\hline
\end{tabular}


TABLE 1 | Continued

\begin{tabular}{|c|c|c|c|c|c|c|c|c|c|}
\hline Material & Species & $\begin{array}{l}\text { Protein } \\
(\% \text { DW })\end{array}$ & $\begin{array}{l}\text { Lipid } \\
\text { (\% DW) }\end{array}$ & $\begin{array}{l}\text { Carbohydrate } \\
(\% \text { DW })\end{array}$ & $\begin{array}{l}\text { Fiber } \\
(\% \text { DW })\end{array}$ & $\begin{array}{c}\text { Ash } \\
(\% \text { DW })\end{array}$ & Target species & $\begin{array}{l}\text { Dietary } \\
\text { inclusion } \\
(\%)\end{array}$ & References \\
\hline \multicolumn{10}{|c|}{ Microscopic origin } \\
\hline \multirow[t]{8}{*}{ Microalgae } & Nannochloropsis oculata & 42.2 & 5.6 & & 0.6 & & Litopenaeus vannamei & 25 & Gamboa-Delgado et al., 2019 \\
\hline & Nannochloropsis granulata & 33.9 & 27.6 & 14.4 & & 7.5 & Litopenaeus vannamei, Onchorhyncus mykiss & $26-29$ & Tibbetts et al., 2017 \\
\hline & Nannochloropsis sp. & $33-51$ & $18-20$ & & & 35 & $\begin{array}{l}\text { Marsupenaeus japonicus, Dicentrachus labrax, } \\
\text { Scopthalmus maximum }\end{array}$ & $7-10$ & $\begin{array}{l}\text { Oswald et al., 2019; Qiao et al., } \\
\text { 2019; Valente et al., 2019; } \\
\text { Adissin et al., } 2020\end{array}$ \\
\hline & Chlorella vulgaris & $58.0-66.4$ & $4.0-9.6$ & 17.3 & 3.3 & $5.1-5.5$ & Clarias gariepinus, Danio rerio & $0.6-30$ & $\begin{array}{l}\text { Raji et al., 2018; Carneiro et al., } \\
2020\end{array}$ \\
\hline & Schizochytrium sp. & $11-16$ & $51-70$ & 19.4 & & $3.8-4.4$ & Ictalurus punctatus, Pagrus major, Salmo salar & $2-11$ & $\begin{array}{l}\text { Li et al., 2009; Kousoulaki et al., } \\
\text { 2016; Seong et al., 2019; } \\
\text { Katerina et al., } 2020\end{array}$ \\
\hline & Tetraselmis suecica & 38.7 & 12.4 & 44.3 & & & Litopenaeus vannamei, Dicentrarchus labrax & $0.7-12$ & $\begin{array}{l}\text { Messina et al., 2019; Sharawy } \\
\text { et al., } 2020\end{array}$ \\
\hline & Tetraselmis sp. (defatted) & 40.6 & 1.3 & & & 14.6 & Sparus aurata & 10 & Pereira et al., 2020 \\
\hline & Isochrysis galbana & 23.2 & 36.6 & 34.5 & & 1.7 & Trachinotus ovatus & 8.6 & He et al., 2018 \\
\hline Cyanobacteria & Arthospira sp. & $59.4-63.2$ & $2.2-7.0$ & 15.0 & $1.2-3.2$ & 4.1 & $\begin{array}{l}\text { Litopenaeus vannamei, Lates calcalifer, } \\
\text { Onchorhyncus mykiss, Salmo salar, Clarias } \\
\text { gariepinus }\end{array}$ & $25-50$ & $\begin{array}{l}\text { Burr et al., 2012; } \\
\text { Gamboa-Delgado et al., 2019; } \\
\text { Raji et al., 2020; Van Vo et al., } \\
2020\end{array}$ \\
\hline Bacteria & Biofloc meal & $23.4-49.0$ & $0.3-1.1$ & $18.6-36.4$ & 12.6 & 13.4-36.6 & Litopenaeus vannamei, Penaeus monodon & $12-15.7$ & $\begin{array}{l}\text { Bauer et al., 2012; Simon et al., } \\
2020\end{array}$ \\
\hline
\end{tabular}




\section{Materials of Macroalgal Origin}

Some macroalgae (seaweeds) species have been studied intensively as feed raw materials, either as phyco-additives that contribute bioactive compounds such as flavonoids, prebiotics, and carotenoids, or as a source of macro- and micro-nutrients. Seaweeds are also known as effective nutrient biosorbents that remove various nutrients from their surrounding environment. Members of the genus Ulva spp. are those seaweeds with greatest potential for aquafeed raw materials. These green macroalgae (Chlorophyta) have a high annual productivity (ca. $838 \mathrm{~g} \mathrm{C} / \mathrm{m}^{2} /$ year) (Chemodanov et al., 2017) and have the potential to be used as feed material and for other human uses. For instance, with its high total ammonia nitrogen (89\%) and phosphate (44\%) removal capacity (Kang et al., 2021), U. pertusa has the potential to be cultured as a phytoremediator in intensive fish or shrimp ponds, in coastal zones, and/or to be cultivated in integrated multitrophic aquaculture (IMTA) systems (Aníbal et al., 2014). The protein content of Ulva spp. may reach up to $32 \% \mathrm{DW}$, with a lipid content of $<2 \% \mathrm{DW}$ (Table 1). Ulva spp. also contains high levels of aspartic acid and glutamic acid as well as alanine and arginine. The apparent digestibility of Ulva spp. proteins by rainbow trout and tilapia is 75.6 and 63.4\%, respectively (Pereira et al., 2012). Various species of Ulva have been studied as a feed material for some aquaculture species, with a maximum inclusion level recorded at 25\% (Yangthong and Ruensirikul, 2020). Gracilaria sp. is one of the most commonly cultured red algae (Rhodophyta). Members of this genus has been consumed and used to produce agar and can contain protein up to $18.9 \%$ DW with a lipid content of $<1 \%$ DW (Xuan et al., 2019). The protein digestibility of Gracilaria vermiculophylla was reported to be about 87.8 and $51.4 \%$ in rainbow trout and Nile tilapia, respectively (Pereira et al., 2012). The utilization of Gracilaria spp. for aquafeed has been tested in various aquaculture species, with the highest inclusion level reported in European seabass at about 25\% (Vizcaíno et al., 2016). Other studies of macroalgal genera in aquafeed have focused on some brown algae (Phaeophyta), such as Macrocystis spp., Ascophyllum nodosum, and Sargassum spp. The inclusion levels of these macroalgae groups, however, were reported to be lower relative to Ulva or Gracilaria. Sargassum muticum, for instance, contains relatively lower protein levels than Ulva and Gracilaria, at a range of 9-17\% DW, with higher protein digestibility in Nile tilapia (71.2\%) compared with that of Gracilaria sp. (Pereira et al., 2012).

\section{Materials of Microscopic Origin}

Materials of microscopic origin are derived from microorganisms such as microalgae, yeast, cyanobacteria, and bacteria. Microalgae contain various essential nutrients such as amino acids, fatty acids, and vitamins as well as bioactive compounds that are beneficial for both aquaculture animals and humans. Studies have recently demonstrated the possibility to generate microalgal biomass using wastewater, which might not suitable for human uses but could be used as a feed material (Dourou et al., 2018, 2020; Malibari et al., 2018). Among the extensively studied marine microalgae, several species that have a high potential as aquafeed raw materials include Nannochloropsis spp., Chlorella spp., Schizochytrium spp., Tetraselmis spp., and Isochrysis spp. (Table 1). Nannochloropsis spp. are known as a source of n-3 highly unsaturated fatty acids (HUFAs) that can be cultured with high productivity (33.6-84.0 tons/ha/year) (Griffiths et al., 2012; Chauton et al., 2015). The members of this genus could be used as an aquafeed material with an inclusion level up to $82 \%$ (Gbadamosi and Lupatsch, 2018). A recent study showed that the use of defatted Nannochloropsis oculata (a by-product of oil extraction for nutraceuticals) and whole cells of Schizochytrium sp. to substitute fishmeal and fish oil in Nile tilapia diet resulted in a $48 \%$ higher final body weight and $8 \%$ lower feed cost per kilogram fish production (Sarker et al., 2020). Arthrospira (Spirulina) spp. are cyanobacteria with substantial productivity (20-90 tons/ha/year) that has been cultured and used as food and feed supplements (Soni et al., 2017). With the high capacity in removing phosphate $(99.97 \%)$ and nitrate $(81.10 \%)$ in water, this group of cyanobacteria has the potential to be cultured in integration with other aquaculture production as a bioremediator (Cardoso et al., 2020). Members of the genus Arthrospira are also known for their nutritional benefits. For example, Arthrospira platensis is reported to have a significantly high protein content (about 60\% DW) (Van Vo et al., 2020) and various high-value bioactive compounds including vitamins, essential lipids, and natural pigments (phycocyanins) (Cuellar-Bermudez et al., 2015). Arthrospira spp. have been tested on various aquaculture species with the highest inclusion level recorded in African catfish, at about 30\%, and may completely substitute fishmeal use (Raji et al., 2020). Although some marine yeast and bacteria have been identified recently, most of the studies involving these microorganisms as aquafeed raw materials are not specific to marine species. Commercially available bacterial meals are mainly produced from natural gas fermentation by using single or mixed species of methanotrophs (Jones et al., 2020), some of which can also be found in marine environment. Bacterial meal is a single-cell protein that can be used in the diet of various animals including aquaculture species (Øverland et al., 2010). A notable aquafeed raw material is biofloc meal, which mainly consists of a heterogenous mix of bacteria. Biofloc can be generated from fish or shrimp wastewater treatment and has a protein content in the range of $23-49 \% \mathrm{DW}$ (Dantas et al., 2016). This material could be used in shrimp feed at an inclusion level up to 60\% (Bauer et al., 2012; Promthale et al., 2019).

\section{THE CHALLENGES OF UTILIZING MARINE-BASED ORGANISMS FOR AQUAFEED AND STRATEGIES TO ENHANCE UTILIZATION}

The utilization of marine-based organisms for feed material is not without challenges. The use of each material is associated with specific challenges that may limit its use in aquafeeds; these include (1) nutritional composition and productivity, which may strongly depend on the environment; (2) risk of contamination by toxins and heavy metals; and (3) presence of antinutritional factors. The productivity and nutritional 
composition of macroalgal- and microbial-based materials could be strongly dependent on the nutrient quantity and composition of the water, which are site and season specific (Mohy El-Din, 2019). Likewise, the productivity and nutritional composition of mussels could depend on the quantity of organic matter, microalgal composition, and the presence of stressors in their environment (Martino et al., 2019). This implies that site selection is an essential strategy to maintain high productivity and high quality of marine-based raw materials. Nutrient-rich environments are also associated with the higher possibility of toxin and heavy metal absorption by extractive marine organisms, which may reduce the safety of the raw materials (Torres et al., 2019). A recent study by Jusadi et al. (2020) demonstrated that accumulation of heavy metals in mussel meal could be alleviated by dietary supplementation of fulvic and humic acids at very low concentrations. Fulvic and humic acids are chelating agents that bind heavy metals to prevent their absorption by the fish, thus avoiding the accumulation of heavy metals in aquaculture organisms. van der Spiegel et al. (2013) suggested that some seaweeds may contain some hazards such as ANFs, dioxins, and pesticides that limit their use as feed and/or food materials. Fermentation and biorefinery technologies that have been well-developed in various food technologies could be applied to these materials to improve their nutritional value and to optimize nutrient digestibility as well as eliminate potential hazards (Bikker et al., 2016; Fleurence, 2016). While some of these raw materials, particularly those of macroalgal origin, are typically lower in protein than current sources; the development of protein concentrates for emerging ingredients may help bolster their use in future aquafeeds (Magnusson et al., 2019). Various hydrolytic processes could be applied to these materials to remove possible contaminants such as heavy metals and toxins to ensure their safety for the fed organisms and ultimately for human consumption (Torres et al., 2019).

\section{CONCLUSIONS AND FUTURE DIRECTIONS}

Marine-based feed materials are promising raw materials for aquafeed development. From a nutritional point of view, marine-based materials are relatively similar, if not superior, to terrestrial-origin materials. The production of unfed marinebased materials does not require freshwater and may enable the retrieval of waste nutrients from the environment, thus

\section{REFERENCES}

Abdel-Warith, A. W. A., Younis, E. S. M. I., and Al-Asgah, N. A. (2016). Potential use of green macroalgae Ulva lactuca as a feed supplement in diets on growth performance, feed utilization and body composition of the African catfish, Clarias gariepinus. Saudi J. Biol. Sci. 23, 404-409. doi: 10.1016/j.sjbs.2015.11.010

Adissin, T. O. O., Manabu, I., Shunsuke, K., Saichiro, Y., Moss, A. S., and Dossou, S. (2020). Effects of dietary Nannochloropsis sp. powder and lipids on the growth performance and fatty acid composition of larval and postlarval kuruma shrimp, Marsupenaeus japonicus. Aquac. Nutr. 26, 186-200. doi: 10.1111/anu.12980 allowing more efficient use of nutrients, reducing the negative impacts of aquaculture on the environment, and promoting the sustainability of marine aquaculture in general. Some of the marine-based feed raw materials are already available commercially, such as seaweeds, microalgae, or bacteria meals; however, the price of these products is still high and is not competitive with conventional feed materials. Thus, more efforts are needed to promote the development of technologies for the production and processing of these materials to enable their commercial use. Further research on the environmental and nutritional requirements of these organisms are needed in order to improve productivity. More studies are also required to elucidate strategies to enhance the nutritional quality of the materials. The development of pretreatment and processing technologies is required to reduce the risks of contamination and antinutritional factors as well as to improve the nutritional quality of the products. Biorefinery technologies that could allow the utilization of all valuable constituents of a raw material in an economically feasible cascading process, with limited to zero waste, could be developed for the efficient use of the raw materials and for the production of high-quality materials for aquafeed production.

\section{AUTHOR CONTRIBUTIONS}

DJ was responsible for the conceptualization, data collection, and manuscript preparation. JE was responsible for data collection and manuscript preparation. MAS contributed to the analysis, interpretation of the data, and information as well as providing critical review to the manuscript in particular those sections relating to the criteria of aquafeed raw materials quality. MS was involved in data interpretation and manuscript revision. IF contributed in data acquisition and analysis as well as manuscript revision. All authors contributed to the article and approved the submitted version.

\section{FUNDING}

Bogor Agricultural University supported the open access publication fee for this minireview.

\section{ACKNOWLEDGMENTS}

The authors would like to thank Bogor Agricultural University for partly fund the publication fee of this minireview.

Agarwal, A., Mhatre, A., Pandit, R., and Lali, A. M. (2020). Synergistic biorefinery of Scenedesmus obliquus and Ulva lactuca in poultry manure towards sustainable bioproduct generation. Bioresour. Technol. 297:122462. doi: 10.1016/j.biortech.2019. 122462

Al-Asgah, N. A., Younis, E. S. M., Abdel-Warith, A. W. A., and Shamlol, F. S. (2016). Evaluation of red seaweed Gracilaria arcuata as dietary ingredient in African catfish, Clarias gariepinus. Saudi J. Biol. Sci. 23, 205-210. doi: 10.1016/j.sjbs.2015.11.006

Anh, N. T. N., Hien, T. T. T., Mathieu, W., Van Hoa, N., and Sorgeloos, P. (2009a). Effect of fishmeal replacement with Artemia biomass as a protein source 
in practical diets for the giant freshwater prawn Macrobrachium rosenbergii. Aquac. Res. 40, 669-680. doi: 10.1111/j.1365-2109.2008.02143.x

Anh, N. T. N., Van Hoa, N., Van Stappen, G., and Sorgeloos, P. (2009b). Effect of different supplemental feeds on proximate composition and Artemia biomass production in salt ponds. Aquaculture 286, 217-225. doi: 10.1016/j.aquaculture.2008.09.030

Aníbal, J., Madeira, H. T., Carvalho, L. F., Esteves, E., Veiga-Pires, C., and Rocha, C. (2014). Macroalgae mitigation potential for fish aquaculture effluents: an approach coupling nitrogen uptake and metabolic pathways using Ulva rigida and Enteromorpha clathrata. Environ. Sci. Pollut. Res. 21, 13324-13334. doi: 10.1007/s11356-013-2427-x

Bauer, W., Prentice-Hernandez, C., Tesser, M. B., Wasielesky, W., and Poersch, L. H. S. (2012). Substitution of fishmeal with microbial floc meal and soy protein concentrate in diets for the Pacific white shrimp Litopenaeus vannamei. Aquaculture 342-343, 112-116. doi: 10.1016/j.aquaculture.2012.02.023

Bikker, P., van Krimpen, M. M., van Wikselaar, P., Houweling-Tan, B., Scaccia, N., van Hal, J. W., et al. (2016). Biorefinery of the green seaweed Ulva lactuca to produce animal feed, chemicals and biofuels. J. Appl. Phycol. 28, 3511-3525. doi: $10.1007 / \mathrm{s} 10811-016-0842-3$

Burr, G. S., Wolters, W. R., Barrows, F. T., and Hardy, R. W. (2012). Replacing fishmeal with blends of alternative proteins on growth performance of rainbow trout (Oncorhynchus mykiss), and early or late stage juvenile Atlantic salmon (Salmo salar). Aquaculture 334-337, 110-116. doi: 10.1016/j.aquaculture.2011.12.044

Cardoso, L. G., Duarte, J. H., Andrade, B. B., Lemos, P. V. F., Costa, J. A. V., Druzian, J. I., et al. (2020). Spirulina sp. LEB 18 cultivation in outdoor pilot scale using aquaculture wastewater: high biomass, carotenoid, lipid and carbohydrate production. Aquaculture 525:735272. doi: $10.1016 /$ j.aquaculture. 2020.735272

Carneiro, W. F., Castro, T. F. D., Orlando, T. M., Meurer, F., de Jesus Paula, D. A., do Carmo RodriguesVirote, B., et al. (2020). Replacing fish meal by Chlorella sp. meal: effects on zebrafish growth, reproductive performance, biochemical parameters and digestive enzymes. Aquaculture 528:735612. doi: 10.1016/j.aquaculture.2020.735612

Chauton, M. S., Reitan, K. I., Norsker, N. H., Tveterås, R., and Kleivdal, H. T. (2015). A techno-economic analysis of industrial production of marine microalgae as a source of EPA and DHA-rich raw material for aquafeed: research challenges and possibilities. Aquaculture 436, 95-103. doi: 10.1016/j.aquaculture.2014.10.038

Chemodanov, A., Jinjikhashvily, G., Habiby, O., Liberzon, A., Israel, A., Yakhini, Z., et al. (2017). Net primary productivity, biofuel production and $\mathrm{CO}_{2}$ emissions reduction potential of Ulva sp. (Chlorophyta) biomass in a coastal area of the Eastern Mediterranean. Energy Convers. Manag. 148, 1497-1507. doi: 10.1016/j.enconman.2017.06.066

Cruz-SuÁrez, L. E., Tapia-Salazar, M., Nieto-López, M. G., Guajardo-Barbosa, C., and Ricque-Marie, D. (2009). Comparison of Ulva clathrata and the kelps Macrocystis pyrifera and Ascophyllum nodosum as ingredients in shrimp feeds. Aquac. Nutr. 15, 421-430. doi: 10.1111/j.1365-2095.2008.00607.x

Cuellar-Bermudez, S. P., Aguilar-Hernandez, I., Cardenas-Chavez, D. L., OrnelasSoto, N., Romero-Ogawa, M. A., and Parra-Saldivar, R. (2015). Extraction and purification of high-value metabolites from microalgae: essential lipids, astaxanthin and phycobiliproteins. Microb. Biotechnol. 8, 190-209. doi: 10.1111/1751-7915.12167

Dantagnan, P., Hernández, A., Borquez, A., and Mansilla, A. (2009). Inclusion of macroalgae meal (Macrocystis pyrifera) as feed ingredient for rainbow trout (Oncorhynchus mykiss): effect on flesh fatty acid composition. Aquac. Res. 41, 87-94. doi: 10.1111/j.1365-2109.2009.02308.x

Dantas, E. M., Valle, B. C. S., Brito, C. M. S., Calazans, N. K. F., Peixoto, S. R. M., and Soares, R. B. (2016). Partial replacement of fishmeal with biofloc meal in the diet of postlarvae of the Pacific white shrimp Litopenaeus vannamei. Aquac. Nutr. 22, 335-342. doi: 10.1111/anu.12249

Diler, I., Tekinay, A. A., Güroy, D., Güroy, B. K., and Soyutürk, M. (2007). Effects of Ulva rigida on the growth, feed intake and body composition of common carp, Cyprinus carpio L. J. Biol. Sci. 7, 305-308. doi: 10.3923/jbs.2007.305.308

Dourou, M., Dritsas, P., Baeshen, M. N., Elazzazy, A., Al-Farga, A., and Aggelis, G. (2020). High-added value products from microalgae and prospects of aquaculture wastewaters as microalgae growth media. FEMS Microbiol. Lett. 367:fnaa081. doi: 10.1093/femsle/fnaa081
Dourou, M., Tsolcha, O. N., Tekerlekopoulou, A. G., Bokas, D., and Aggelis, G. (2018). Fish farm effluents are suitable growth media for Nannochloropsis gaditana, a polyunsaturated fatty acid producing microalga. Eng. Life Sci. 18, 851-860. doi: 10.1002/elsc.201800064

Ergün, S., Soyutürk, M., Güroy, B., Güroy, D., and Merrifield, D. (2009). Influence of Ulva meal on growth, feed utilization, and body composition of juvenile Nile tilapia (Oreochromis niloticus) at two levels of dietary lipid. Aquac. Int. 17, 355-361. doi: 10.1007/s10499-008-9207-5

FAO (2020). The State of World Fisheries and Aquaculture 2020. Sustainability in Action. Rome: Food and Agriculture Organization of the United Nations.

Fleurence, J. (2016). "Seaweeds as food," in Seaweed in Health and Disease Prevention, eds J. Fleurence and I. Levine (London: Academic Press), 149-167.

Francis, G., Makkar, H. P. S., and Becker, K. (2001). Antinutritional factors present in plant-derived alternate fish feed ingredients and their effects in fish. Aquaculture 199, 197-227. doi: 10.1016/S0044-8486(01)00526-9

Gamboa-Delgado, J., Morales-Navarro, Y. I., Nieto-López, M. G., VillarrealCavazos, D. A., and Cruz-Suárez, L. E. (2019). Assimilation of dietary nitrogen supplied by fish meal and microalgal biomass from Spirulina (Arthrospira platensis) and Nannochloropsis oculata in shrimp Litopenaeus vannamei fed compound diets. J. Appl. Phycol. 31, 2379-2389. doi: 10.1007/s10811-019-1732-2

Gbadamosi, O. K., and Lupatsch, I. (2018). Effects of dietary Nannochloropsis salina on the nutritional performance and fatty acid profile of Nile tilapia, Oreochromis niloticus. Algal Res. 33, 48-54. doi: 10.1016/j.algal.2018.04.030

Gentry, R. R., Froehlich, H. E., Grimm, D., Kareiva, P., Parke, M., Rust, M., et al. (2017). Mapping the global potential for marine aquaculture. Nat. Ecol. Evol. 1, 1317-1324. doi: 10.1038/s41559-017-0257-9

Glencross, B. D., Baily, J., Berntssen, M. H. G., Hardy, R., MacKenzie, S., and Tocher, D. R. (2020). Risk assessment of the use of alternative animal and plant raw material resources in aquaculture feeds. Rev. Aquac. 12, 703-758. doi: $10.1111 /$ raq. 12347

Griffiths, M. J., van Hille, R. P., and Harrison, S. T. L. (2012). Lipid productivity, settling potential and fatty acid profile of 11 microalgal species grown under nitrogen replete and limited conditions. J. Appl. Phycol. 24, 989-1001. doi: 10.1007/s10811-011-9723-y

Guerreiro, I., Magalhães, R., Coutinho, F., Couto, A., Sousa, S., Delerue-Matos, C., et al. (2019). Evaluation of the seaweeds Chondrus crispus and Ulva lactuca as functional ingredients in gilthead seabream (Sparus aurata). J. Appl. Phycol. 31, 2115-2124. doi: 10.1007/s10811-018-1708-7

Güroy, B., Ergün, S., Merrifield, D. L., and Güroy, D. (2013). Effect of autoclaved Ulva meal on growth performance, nutrient utilization and fatty acid profile of rainbow trout, Oncorhynchus mykiss. Aquac. Int. 21, 605-615. doi: 10.1007/s10499-012-9592-7

Hafezieh, M., Ajdari, D., Ajdehakosh Por, A., and Hosseini, S. H. (2014). Using Oman Sea Sargassum illicifolium meal for feeding white leg shrimp Litopenaeus vannamei. Iran. J. Fish. Sci. 13, 73-80.

He, Y., Lin, G., Rao, X., Chen, L., Jian, H., Wang, M., et al. (2018). Microalga Isochrysis galbana in feed for Trachinotus ovatus: effect on growth performance and fatty acid composition of fish fillet and liver. Aquac. Int. 26, 1261-1280. doi: 10.1007/s10499-018-0282-y

Herawati, V. E., Pinandoyo, Darmanto, Y. S., Rismaningsih, N., Hutabarat, J., Prayitno, S. B., et al. (2020). Effect of feeding with Phronima sp. on growth, survival rate and nutrient value content of Pacific white shrimp (Litopenaeus vannamei) post-larvae. Aquaculture 529:735674. doi: 10.1016/j.aquaculture.2020.735674

Hua, K., Cobcroft, J. M., Cole, A., Condon, K., Jerry, D. R., Mangott, A., et al. (2019). The future of aquatic protein: implications for protein sources in aquaculture diets. One Earth 1, 316-329. doi: 10.1016/j.oneear.2019.10.018

Jones, S. W., Karpol, A., Friedman, S., Maru, B. T., and Tracy, B. P. (2020). Recent advances in single cell protein use as a feed ingredient in aquaculture. Curr. Opin. Biotechnol. 61, 189-197. doi: 10.1016/j.copbio.2019.12.026

Jusadi, D., Aprilia, T., Setiawati, M., Agus Suprayudi, M., and Ekasari, J. (2020) Dietary supplementation of fulvic acid for growth improvement and prevention of heavy metal accumulation in Nile tilapia fed with green mussel. Egypt J. Aquat. Res. 46, 295-301. doi: 10.1016/j.ejar.2020.04.002

Kang, Y. H., Kim, S., Choi, S. K., Lee, H. J., Chung, I. K., and Park, S. R. (2021). A comparison of the bioremediation potential of five seaweed species in an 
integrated fish-seaweed aquaculture system: implication for a multi-species seaweed culture. Rev. Aquac. 13, 353-364. doi: 10.1111/raq.12478

Katerina, K., Berge, G. M., Turid, M., Aleksei, K., Grete, B., Trine, Y., et al. (2020). Microalgal Schizochytrium limacinum biomass improves growth and filet quality when used long-term as a replacement for fish oil, in modern salmon diets. Front. Mar. Sci. 7:57. doi: 10.3389/fmars.2020.00057

Kousoulaki, K., Mørkøre, T., Nengas, I., Berge, R. K., and Sweetman, J. (2016). Microalgae and organic minerals enhance lipid retention efficiency and fillet quality in Atlantic salmon (Salmo salar L.). Aquaculture 451, 47-57. doi: 10.1016/j.aquaculture.2015.08.027

Langeland, M., Vidakovic, A., Vielma, J., Lindberg, J. E., Kiessling, A., and Lundh, T. (2016). Digestibility of microbial and mussel meal for Arctic charr (Salvelinus alpinus) and Eurasian perch (Perca fluviatilis). Aquac. Nutr. 22, 485-495. doi: $10.1111 /$ anu. 12268

Laramore, S., Baptiste, R., Wills, P. S., and Hanisak, M. D. (2018). Utilization of IMTA-produced Ulva lactuca to supplement or partially replace pelleted diets in shrimp (Litopenaeus vannamei) reared in a clear water production system. J. Appl. Phycol. 30, 3603-3610. doi: 10.1007/s10811-018-1485-3

Li, M. H., Robinson, E. H., Tucker, C. S., Manning, B. B., and Khoo, L. (2009). Effects of dried algae Schizochytrium sp., a rich source of docosahexaenoic acid, on growth, fatty acid composition, and sensory quality of channel catfish Ictalurus punctatus. Aquaculture 292, 232-236. doi: 10.1016/j.aquaculture.2009.04.033

Madibana, M. J., Mlambo, V., Lewis, B., and Fouché, C. (2017). Effect of graded levels of dietary seaweed (Ulva sp.) on growth, hematological and serum biochemical parameters in dusky kob, Argyrosomus japonicus, sciaenidae. Egypt J. Aquat. Res. 43, 249-254. doi: 10.1016/j.ejar.2017.09.003

Magnusson, M., Glasson, C. R. K., Vucko, M. J., Angell, A., Neoh, T. L., and de Nys, R. (2019). Enrichment processes for the production of highprotein feed from the green seaweed Ulva ohnoi. Algal Res. 41:101555. doi: 10.1016/j.algal.2019.101555

Malibari, R., Sayegh, F., Elazzazy, A. M., Baeshen, M. N., Dourou, M., and Aggelis, G. (2018). Reuse of shrimp farm wastewater as growth medium for marine microalgae isolated from Red Sea - Jeddah. J. Clean. Prod. 198, 160-169. doi: 10.1016/j.jclepro.2018.07.037

Martino, P. A., Carlon, D. B., and Kingston, S. E. (2019). Blue mussel (Genus Mytilus) transcriptome response to simulated climate change in the gulf of maine. J. Shellfish Res. 38, 587-602. doi: 10.2983/035.038.0310

Messina, M., Bulfon, C., Beraldo, P., Tibaldi, E., and Cardinaletti, G. (2019). Intestinal morpho-physiology and innate immune status of European sea bass (Dicentrarchus labrax) in response to diets including a blend of two marine microalgae, Tisochrysis lutea and Tetraselmis suecica. Aquaculture 500, 660-669. doi: 10.1016/j.aquaculture.2018.09.054

Mohy El-Din, S. M. (2019). Temporal variation in chemical composition of Ulva lactuca and Corallina mediterranea. Int. J. Environ. Sci. Technol. 16, 5783-5796. doi: 10.1007/s13762-018-2128-6

Mongile, F., Mandrioli, L., Mazzoni, M., Pirini, M., Zaccaroni, A., Sirri, R., et al. (2015). Dietary inclusion of mussel meal enhances performance and improves feed and protein utilization in common sole (Solea solea, linnaeus, 1758) juveniles. J. Appl. Ichthyol. 31, 1077-1085. doi: 10.1111/jai.12895

Nagappan, T., and Vairappan, C. S. (2014). Nutritional and bioactive properties of three edible species of green algae, genus Caulerpa (Caulerpaceae). J. Appl. Phycol. 26, 1019-1027. doi: 10.1007/s10811-013-0147-8

Oswald, A. T. O., Ishikawa, M., Koshio, S., Yokoyama, S., Moss, A. S., and Serge, D. (2019). Nutritional evaluation of Nannochloropsis powder and lipid as alternative to fish oil for kuruma shrimp, Marsupenaeus japonicus. Aquaculture 504, 427-436. doi: 10.1016/j.aquaculture.2019.02.028

Øverland, M., Tauson, A. H., Shearer, K., and Skrede, A. (2010). Evaluation of methane-utilising bacteria products as feed ingredients for monogastric animals. Arch. Anim. Nutr. 64, 171-189. doi: 10.1080/17450391003691534

Pereira, H., Sardinha, M., Santos, T., Gouveia, L., Barreira, L., Dias, J., et al. (2020). Incorporation of defatted microalgal biomass (Tetraselmis sp. CTP4) at the expense of soybean meal as a feed ingredient for juvenile gilthead seabream (Sparus aurata). Algal Res. 47:101869. doi: 10.1016/j.algal.2020.101869

Pereira, R., Valente, L. M. P., Sousa-Pinto, I., and Rema, P. (2012). Apparent nutrient digestibility of seaweeds by rainbow trout (Oncorhynchus mykiss) and Nile tilapia (Oreochromis niloticus). Algal Res. 1, 77-82. doi: $10.1016 /$ j.algal.2012.04.002
Promthale, P., Pongtippatee, P., Withyachumnarnkul, B., and Wongprasert, K. (2019). Bioflocs substituted fishmeal feed stimulates immune response and protects shrimp from Vibrio parahaemolyticus infection. Fish Shellfish Immunol. 93, 1067-1075. doi: 10.1016/j.fsi.2019.07.084

Puspitasari, W., Jusadi, D., Setiawati, M., Ekasari, J., Nur, A., and Sumantri, I. (2019). Utilization of green algae Caulerpa racemosa as feed ingredient for tiger shrimp Penaeus monodon. J. Akuakultur Indones. 18, 162-171. doi: 10.19027/jai.18.2.162-171

Putra, D. F., Rahmawati, M., Abidin, M. Z., and Ramlan, R. (2019). Dietary administration of sea grape powder (Caulerpa lentillifera) effects on growth and survival rate of black tiger shrimp (Penaeus monodon). IOP Confer. Ser. Earth Environ. Sci. 348:012100. doi: 10.1088/1755-1315/348/1/012100

Putri, N. T., Jusadi, D., Setiawati, M., and Sunarno, M. T. D. (2017). Potential use of green algae Caulerpa lentillifera as feed ingredient in the diet of nile tilapia Oreochromis niloticus. J. Akuakultur Indones. 16:195. doi: 10.19027/jai.16.2.195-203

Qiao, H., Hu, D., Ma, J., Wang, X., Wu, H., and Wang, J. (2019). Feeding effects of the microalga Nannochloropsis sp. on juvenile turbot (Scophthalmus maximus L.). Algal Res. 41:101540. doi: 10.1016/j.algal.2019.101540

Qiu, X., Neori, A., Kim, J. K., Yarish, C., Shpigel, M., Guttman, L., et al. (2018). Evaluation of green seaweed Ulva sp. as a replacement of fish meal in plantbased practical diets for Pacific white shrimp, Litopenaeus vannamei. J. Appl. Phycol. 30, 1305-1316. doi: 10.1007/s10811-017-1278-0

Raji, A. A., Alaba, P. A., Yusuf, H., Abu Bakar, N. H., Mohd Taufek, N., Muin, H., et al. (2018). Fishmeal replacement with Spirulina Platensis and Chlorella vulgaris in African catfish (Clarias gariepinus) diet: effect on antioxidant enzyme activities and haematological parameters. Res. Vet. Sci. 119, 67-75. doi: 10.1016/j.rvsc.2018.05.013

Raji, A. A., Jimoh, W. A., Bakar, N. H. A., Taufek, N. H. M., Muin, H., Alias, Z., et al. (2020). Dietary use of Spirulina (Arthrospira) and Chlorella instead of fish meal on growth and digestibility of nutrients, amino acids and fatty acids by African catfish. J. Appl. Phycol. 32, 1763-1770. doi: 10.1007/s10811-02002070-y

Sarker, P. K., Kapuscinski, A. R., McKuin, B., Fitzgerald, D. S., Nash, H. M., and Greenwood, C. (2020). Microalgae-blend tilapia feed eliminates fishmeal and fish oil, improves growth, and is cost viable. Sci. Rep. 10, 1-14. doi: 10.1038/s41598-020-75289-x

Seong, T., Matsutani, H., Haga, Y., Kitagima, R., and Satoh, S. (2019). First step of non-fish meal, non-fish oil diet development for red seabream, (Pagrus major), with plant protein sources and microalgae Schizochytrium sp. Aquac. Res. 50, 2460-2468. doi: 10.1111/are.14199

Sharawy, Z. Z., Ashour, M., Abbas, E., Ashry, O., Helal, M., Nazmi, H., et al. (2020). Effects of dietary marine microalgae, Tetraselmis suecica, on production, gene expression, protein markers and bacterial count of Pacific white shrimp Litopenaeus vannamei. Aquac. Res. 51, 2216-2228. doi: 10.1111/are.14566

Shi, Q., Rong, H., Hao, M., Zhu, D., Aweya, J. J., Li, S., et al. (2019). Effects of dietary Sargassum horneri on growth performance, serum biochemical parameters, hepatic antioxidant status, and immune responses of juvenile black sea bream Acanthopagrus schlegelii. J. Appl. Phycol. 31, 2103-2113. doi: 10.1007/s10811-018-1719-4

Shpigel, M., Guttman, L., Shauli, L., Odintsov, V., Ben-Ezra, D., and Harpaz, S. (2017). Ulva lactuca from an Integrated Multi-Trophic Aquaculture (IMTA) biofilter system as a protein supplement in gilthead seabream (Sparus aurata) diet. Aquaculture 481, 112-118. doi: 10.1016/j.aquaculture.2017.08.006

Silva, D. M., Valente, L. M. P., Sousa-Pinto, I., Pereira, R., Pires, M. A., Seixas, F., et al. (2015). Evaluation of IMTA-produced seaweeds (Gracilaria, Porphyra, and Ulva) as dietary ingredients in Nile tilapia, Oreochromis niloticus L., juveniles. Effects on growth performance and gut histology. J. Appl. Phycol. 27, 1671-1680. doi: 10.1007/s10811-014-0453-9

Simon, C. J., Truong, H. H., Noble, T. H., Osborne, S. A., Wynne, J. W., and Wade, N. M. (2020). Microbial biomass, marine invertebrate meals and feed restriction influence the biological and gut microbiota response of shrimp Penaeus monodon. Aquaculture 520:734679. doi: 10.1016/j.aquaculture.2019.734679

Soni, R. A., Sudhakar, K., and Rana, R. S. (2017). Spirulina - from growth to nutritional product: a review. Trends Food Sci. Technol. 69, 157-171. doi: 10.1016/j.tifs.2017.09.010

Sotoudeh, E., and Jafari, M. (2017). Effects of dietary supplementation with red seaweed, Gracilaria pygmaea, on growth, carcass composition and hematology 
of juvenile rainbow trout, Oncorhynchus mykiss. Aquac. Int. 25, 1857-1867. doi: 10.1007/s10499-017-0158-6

Suplicy, F. M. (2020). A review of the multiple benefits of mussel farming. Rev. Aquac. 12, 204-223. doi: 10.1111/raq.12313

Suryaningrum, L. H., Dedi, J., Setiawati, M., and Sunarno, M. T. D. (2017). Nutrient composition and apparent digestibility coefficient of Ulva lactuca meal in the Nile tilapia (Oreochromis niloticus). AACL Bioflux 10, 77-86.

Tibbetts, S. M., Yasumaru, F., and Lemos, D. (2017). In vitro prediction of digestible protein content of marine microalgae (Nannochloropsis granulata) meals for Pacific white shrimp (Litopenaeus vannamei) and rainbow trout (Oncorhynchus mykiss). Algal Res. 21, 76-80. doi: 10.1016/j.algal.2016.11.010

Torres, M. D., Kraan, S., and Domínguez, H. (2019). Seaweed biorefinery. Rev. Environ. Sci. Biotechnol. 18, 335-388. doi: 10.1007/s11157-019-09496-y

Turchini, G. M., Trushenski, J. T., and Glencross, B. D. (2019). Thoughts for the future of aquaculture nutrition: realigning perspectives to reflect contemporary issues related to judicious use of marine resources in aquafeeds. N. Am. J. Aquac. 81, 13-39. doi: 10.1002/naaq.10067

Valente, L. M. P., Custódio, M., Batista, S., Fernandes, H., and Kiron, V. (2019). Defatted microalgae (Nannochloropsis sp.) from biorefinery as a potential feed protein source to replace fishmeal in European sea bass diets. Fish Physiol. Biochem. 45, 1067-1081. doi: 10.1007/s10695-019-00621-w

Valenti, W. C., Kimpara, J. M., de L. Preto, B., and Moraes-Valenti, P. (2018). Indicators of sustainability to assess aquaculture systems. Ecol. Indic. 88, 402-413. doi: 10.1016/j.ecolind.2017.12.068

van der Spiegel, M., Noordam, M. Y., and van der Fels-Klerx, H. J. (2013). Safety of novel protein sources (insects, microalgae, seaweed, duckweed, and rapeseed) and legislative aspects for their application in food and feed production. Compr. Rev. Food Sci. Food Saf. doi: 10.1111/1541-4337.12032

Van Vo, B., Siddik, M. A. B., Fotedar, R., Chaklader, M. R., Hanif, M. A., Foysal, M. J., et al. (2020). Progressive replacement of fishmeal by raw and enzymetreated alga, Spirulina platensis influences growth, intestinal micromorphology and stress response in juvenile barramundi, Lates calcarifer. Aquaculture 529:735741. doi: 10.1016/j.aquaculture.2020.735741

Vizcaíno, A. J., Mendes, S. I., Varela, J. L., Ruiz-Jarabo, I., Rico, R., Figueroa, F. L., et al. (2016). Growth, tissue metabolites and digestive functionality in Sparus aurata juveniles fed different levels of macroalgae, Gracilaria cornea and Ulva rigida. Aquac. Res. 47, 3224-3238. doi: 10.1111/are.12774

Wagner, L., Gómez-Requeni, P., Moazzami, A. A., Lundh, T., Vidakovic, A., Langeland, M., et al. (2019). 1H NMR-based metabolomics and lipid analyses revealed the effect of dietary replacement of microbial extracts or mussel meal with fish meal to arctic charr (Salvelinus alpinus). Fishes 4:46. doi: 10.3390/fishes4030046
Wang, C., Hu, W., Wang, L., Qiao, H., Wu, H., and Xu, Z. (2019). Effects of dietary supplementation with Sargassum horneri meal on growth performance, body composition, and immune response of juvenile turbot. J. Appl. Phycol. 31, 771-778. doi: 10.1007/s10811-0181590-3

Weiß, M., and Buck, B. H. (2017). Partial replacement of fishmeal in diets for turbot (Scophthalmus maximus, Linnaeus, 1758) culture using blue mussel (Mytilus edulis, Linneus, 1758) meat. J. Appl. Ichthyol. 33, 354-360. doi: $10.1111 /$ jai.13323

Xuan, X., Li, W., Zhu, W., and Wang, S. (2019). Effects of different levels of macroalga Gracilaria lemaneiformis on growth performance and feed utilization on the red sea bream, Pagrosomus major. J. Appl. Phycol. 31, 3213-3222. doi: 10.1007/s10811-019-01787-9

Xuan, X., Wen, X., Li, S., Zhu, D., and Li, Y. (2013). Potential use of macro-algae Gracilaria lemaneiformis in diets for the black sea bream, Acanthopagrus schlegelii, juvenile. Aquaculture 412-413, 167-172. doi: 10.1016/j.aquaculture.2013.07.022

Yangthong, M., and Ruensirikul, J. (2020). Feed intake stimulation of juvenile spotted scat (Scatophagus argus Linnaeus, 1766) using dietary seaweed supplementation (Ulva sp.). Aquaculture 529:735626. doi: 10.1016/j.aquaculture.2020.735626

Yeganeh, S., and Adel, M. (2019). Effects of dietary algae (Sargassum ilicifolium) as immunomodulator and growth promoter of juvenile great sturgeon (Huso huso Linnaeus, 1758). J. Appl. Phycol. 31, 2093-2102. doi: 10.1007/s10811-018-1673-1

Younis, E. S. M., Al-Quffail, A. S., Al-Asgah, N. A., Abdel-Warith, A. W. A., and Al-Hafedh, Y. S. (2018). Effect of dietary fish meal replacement by red algae, Gracilaria arcuata, on growth performance and body composition of Nile tilapia Oreochromis niloticus. Saudi J. Biol. Sci. 25, 198-203. doi: 10.1016/j.sjbs.2017.06.012

Conflict of Interest: The authors declare that the research was conducted in the absence of any commercial or financial relationships that could be construed as a potential conflict of interest.

Copyright (C) 2021 Jusadi, Ekasari, Suprayudi, Setiawati and Fauzi. This is an openaccess article distributed under the terms of the Creative Commons Attribution License (CC BY). The use, distribution or reproduction in other forums is permitted, provided the original author(s) and the copyright owner(s) are credited and that the original publication in this journal is cited, in accordance with accepted academic practice. No use, distribution or reproduction is permitted which does not comply with these terms. 